\title{
ANALISIS PENDAPATAN USAHATANI KAKAO DI DESA SIONTAPINA KECAMATAN LASALIMU SELATAN KABUPATEN BUTON
}

\author{
Suriadi \\ Program Studi Agribisnis Fakultas Peranian \\ Universitas Muhammadiyah Buton \\ Jln. Betoambari No. 36 Baubau \\ Email: Suriadiyah@yahoo.com
}

\begin{abstract}
This research aims to analyze the amount of income earned by farmers from cocoa farming. This research was conducted from May to June 2013 in Siontapina village of Lasalimu Sub district of Buton Regency. The research sample is determined by sample random techniques (Simple random sampling method) with 30 people. Research data obtained through direct interview with farmer respondents using a questionnaire. While secondary data is obtained from the village office/administrative and related institutions were analyzed descriptively and quantitatively used to determine the level of income by the formula: $N 1=T R-T C, T R=P x$ $Q, T C=T F C+T V C$, comparative analysis: Revenue - cost ratio for comparing the difference between the value of production and the cost of production by the formula $R C$ ratio $: R / C=$ Revenue (TR) / Total Cost (TC). The results showed that the income earned by farmers from cocoa farming with land area ranges between 1 to 3 ha of IDR 8,109,000 $35,437,000 / y e a r$, with income per capita monthly average IDR 675,750,00 so that Siontapina village had not been considered poor, the average income earned by farmers in cocoa farming with land area- average of 2,05 hectares of IDR 18,426,767/year. Cocoa farming by farmers still do because based on the results of feasibility analysis obtained a value of 5.7. This illustrates that every cost IDR 1.00 incurred by farmers will gain acceptance by IDR 5.7. So, farmers are expected to carry cocoa farming is more responsive and responsive to the presence of new technologies that can increase the cocoa production.
\end{abstract}

Keyword: revenue, cost of production, cocoa.

\begin{abstract}
Abstrak
Penelitian bertujuan untuk menganalisis besarnya pendapatan yang diterima oleh petani dari usahatani kakao. Penelitian ini dilaksanakan pada bulan Mei sampai Juni 2013 di Desa Siontapina Kecamatan Lasalimu Kabupaten Buton. Sampel penelitian ditentukan dengan teknik acak sederhana (simple random sampling method) sebanyak 30 orang. Data penelitian diperoleh melalui wawancara langsung dengan petani responden dengan menggunakan daftar pertanyaan (kuesioner). Sedangkan data sekunder adalah data yang diperoleh dari kantor desa/kelurahan dan instansi terkait dan dianalisis secara deskriptip kuantitatif digunakan untuk mengetahui besarnya tingkat pendapatan dengan rumus: $\mathrm{NI}=\mathrm{TR}-\mathrm{TC}, T R=P x Q, T C$ $=T F C+T V C$. Analisis Perbandingan: Revenue - Cost Ratio untuk membandingkan antara selisih besarnya nilai produksi dan besarnya biaya produksi dengan rumus $\mathrm{RC}$ ratio: $\mathrm{R} / \mathrm{C}=$ Penerimaan (TR) / Biaya Total (TC). Hasil penelitian menunjukkan bahwa pendapatan yang diterima oleh petani dari usahatani kakao dengan luas lahan berkisar antara 1 - 3 hektar sebesar Rp 8.109.000 - 35.437.000/tahun, dengan pendapatan per kapita perbulan rata-rata Rp
\end{abstract}


675.750, sehingga Desa Siontapina dikategorikan tidak miskin, pendapatan rata-rata yang diterima oleh petani pada usahatani kakao dengan luas lahan rata - rata 2,05 Hektar sebesar Rp 18.426.767/Tahun. Usahatani kakao yang dilakukan oleh petani tetap dilakukan sebab berdasarkan hasil analisis kelayakan usaha diperoleh nilai sebesar 5,7. Hal ini memberikan gambaran bahwa setiap Rp 1 biaya yang dikeluarkan oleh petani akan memperoleh penerimaan sebesar Rp 5,7. Dengan demikian petani diharapkan dapat melakukan kegiatan usahatani kakao lebih responsif dan tanggap terhadap adanya teknologi baru yang dapat meningkatkan produksi kakao.

Kata Kunci: Pendapatan, biaya produksi, kakao

\section{PENDAHULUAN}

Pembangunan ekonomi yang Indonesia dilakukan melalui berbagai sektor, salah satunya adalah sektor pertanian. Sektor pertanian dalam arti luas menurut Mubyarto (1989) mencakup pertanian rakyat, perkebunan yang meliputi perkebunan rakyat, kehutanan, petemakan dan perikanan yang terdiri dari perikanan darat dan perikanan laut.

Pembangunan pertanian diarahkan untuk meningkatkan pendapatan dan taraf hidup petani, memperluas lapangan pekerjaan dan kesempatan berusaha, serta mengisi pasar, baik pasar dalam negeri maupun pasar luar negeri melalui pertanian yang maju, efisien dan tangguh sehingga mampu meningkatkan penganekaragaman hasil, meningkatkan mutu dan derajat pengolahan produksi serta menunjang pembangunan wilayah. Meskipun peranan sektor pertanian secara relatif semakin berkurang karena terjadinya proses transportasi structural perekonomian nasional akibat keberhasilan pembanguan ekonomi yang dicapai namun sektor pertanian akan tetap memegang peranan yang sangat penting dalam struktur pertanian nasional, hal ini dapat dilihat dari besarnya Produk Domestik Broto Indonesia tahun 2005 sebesar 1.749,5 triliun, dimana $13,40 \%$ berasal dari sektor pertanian (Anonim, 2005).

Produk Domestic Bruto (PDB) merupakan salah satu indicator untuk mengukur kinerja suatu perekonomian. Konsep Dasar PDB menurut pendekatan produksi adalah jumlah nilai tambah yang dihasilkan oleh seluruh unit usaha dalam suatu Negara tertentu atau merupakan jumlah nilai barang dan jasa yang dihasilkan oleh seluruh unit eknomi pada periode tertentu. Produk Domestik Bruto (PDB) dapat digunakan untuk menghitung pertumbuhan ekonomi pada suatu Negara.

Pemerintah mulai menaruh perhatian disektor pertanian sebagai bagian integral dari sistem pembanguna nasional semakin penting dan strategis searah dengan arus perubahan lingkup nasional dan intemasional. Sektor pertanian yang tangguh merupakan akumulasi riil dari penggunaan tenaga kerja (petani yang potesial, luas lahan yang produktif, teknologi tepat guna dan modal serta kemampuan manajerial.

Pembangunan di bidang pertanian merupakan salah satu bagian dari pembangunan nasional yang pada dasamya bertujuan untuk meningkatkan pendapatan dan kesejahteraan petani. Sebagian besar penduduk Sulawesi Tenggara bermukim di pedesaan dengan keadaan social ekonomi yang belum maju, sehingga diperlukan adanya upaya peningkatan pendapatan masyarakat secara keseluruhan, utamanya bagi mereka yang tergolong yang berpendapatan rendah seperti petani. Salah satu komoditas perkebunan yang dikembangkan oleh petani adalah tanama kakao. 
Kakao adalah salah satu komoditas pertanian yang memiliki peranan penting dalam pembangunan karena dilihat dari peran ekonomi kedepan sebagai lapangan kerja bagi rumah tangga petani, buruh tani dan penggunaan input pertanian juga memberikan kesempatan kerja dan berusaha, industri makanan, rumah makan/restoran dan industri minum, oleh karena itu pengusahaan perkebunan kakao tidak saja mampu menampung kesempatan kerja juga menjadi sumber pendapatan bagi sebagian masyarakat pedesaaan dan masyarakat perkotaan.

Sasaran utama pembangunan pertanian dewasa ini adalah peningkatan produksi pertanian dan pendapatan petani, karena itu kegiatan disektor pertanian diusahakan agar dapat berjalan lancar dengan peningkatan produksi pangan baik melalui intensifikasi, ekstensifkasi dan diversifikasi pertanian yang diharapkan dapat memperbaiki taraf hidup petani, memperluas lapangan pekerjaan bagi golongan masyarakat yang masih tergantung pada sektor pertanian.

Pengembangan komoditas pertanian khususnya sektor perkebunan di Sulawesi Tenggara dikembangkan oleh 101.062 petani pada lahan seluas 127.447,02 Ha dengan produktifitas 986,99 kg/ha (Disbunhort, 2009). Salah satu kabupaten yang berada dalam kawasan Sulawesi tenggara yang cuku potensial untuk pengembangan tanaman kakao adalah Kabupaten Buton. Berdasarkan data statistik Kabupaten Buton Tahun 2010, luas tanam kakao 9.745 Ha dengan total produksi mencapai 7.265 Ton. Salah satu desa yang ada di Kabupaten Buton adalah Desa Siontapina yang berada pada wilayah Kecamatan Lasalimu Selatan, Desa Siontapina merupakan salah satu sentra produksi kakao yang cukup potensial, hal ini dilihat dari luas panen mencapai 103 Ha dengan total produksi mencapai 87 ton. (Buton Dalam Angka 2012).

Berdasarkan kondisi yang ada, bahwa masyarakat Desa Siontapina Kecamatan Tontonunu mempunyai ketergantungan ekonomi pada usahatani kakao dalam memenuhi kebutuhan hidup sehari dan tanaman kakao tersebut mempunyai nilai ekonomi tinggi karena pangsa pasar yang terbuka luas, baik dari pasar nasional maupun pasar intemasional. Namun hal tersebut belum sepenuhnya dimanfaatkan oleh petani karena tuntutan keseragaman kualitas dan kesinambungan produk belum terpenuhi sehingga kesempatan untuk memperoleh pendapatan yang tinggi dari nilai komoditas tersebut belum mampu diraih.

Tujuan penelitian ini adalah untuk mengetahui besamya pendapatan yang diterima oleh petani dari usahatani kakao di Desa Siontapina Kecamatan Lasalimu Kabupaten Buton.

Hasil penelitian ini diharapkan dapat berguna sebagai :

1. Bahan informasi bagi para petani untuk menilai keberhasilan usahataninya dan sekaligus menentukan langkah atau cara yang tepat dalam mengembangkan usahataninya khususnya kakao. 2. Bahan kajian dan referensi bagi pengembangan keilmuan yang lebih luas, khususnya di bidang usahatani kakao dengan memanfaatkan teknologi sesuai anjuran, 3 . Bahan informasi dan masukan bagi pemerintah khususnya instansi terkait, dalam hal ini Dinas Pertanian Kabupaten Buton sebagai pelaku kebijakan di bidang pertanian, 4. Sebagai bahan informasi dan acuan referensi bagi peneliti selanjutnya.

METODE PENELITIAN 
Penelitian ini dilaksanakan bulan Mei sampai Juni 2013 di Desa Siontapina Kecamatan Lasalimu Selatan Kabupaten Buton. Penentuan lokasi penelitian dilakukan secara purposive dengan pertimbangan 1. Desa Siontapina merupakan salah satu desa yang mayoritas penduduknya menggantungkan hidupnya dari usahatani kakao, 2. Desa Siontapina merupakan salah satu desa sentra produksi kakao yang adadi Kecamatan Lasalimu Selatan.

Populasi dalam penelitian ini adalah keseluruhan petani di Desa Siontapina yang mengusahakan tanaman kakao yang berjumlah 150 orang (KK). Penentuan Sampel dilakukan dengan cara acak sederhana (Simple random sampling) dengan mengambil 20\% dari jumlah populasi sebanyak 30 orang. Menurut Arikunto (1993) jika populasi diatas 100 orang maka dapat mengambil sampel 20\% - 25\% namun jika popolasi dibawah 100 orang maka mengambil sampel seluruhnya.

Data penelitian ini terdiri dari data primer dan data sekunder. Data primer adalah data yang diperoleh melalui wawancara dengan petani responden dengan menggunakan daftar pertanyaan (kuesioner). Sedangkan data sekunder adalah data yang diperoleh dari kantor desa/kelurahan dan instansi terkait.

Variabel dalam penelitian ini adalah :

1. Ideiititas responden: umur, pendidikan formal, pengalaman berusahatani, jumlah tanggungan keluarga, luas lahan garapan.

2. Produksi kakao $(\mathrm{Kg})$

3. Harga jual $(\mathrm{Rp} / \mathrm{Kg})$.

4. Biaya produksi usahatani kakao.

Untuk mencapai tujuan penelitian ini, maka data yang diperoleh ditabulasi sesuai kebutuhan, selanjutnya dianalisis secara deskriptif kualitatif digunakan untuk menjelaskan tentang karakteristik petani responden dan usahataninya. Sedangkan analisis deskriptif kuantitatif digunakan untuk mengetahui besarnya tingkat pendapatan dengan rumus (Soeharjo dan Dahlan Patong 1984) dengan formula :

N1 - TR - TC

$\mathrm{TR}=\mathrm{P} \times \mathrm{Q}$

$\mathrm{TC}=\mathrm{TFC}+\mathrm{TVC}$

Analisis Perbandingan: Revenue - Cost Ratio untuk membandingkan antara selisih besarnya nilai produksi dan besarnya biaya produksi (Soekartawi, 1996) dengan rumus :

$\mathrm{RC}$ ratio $: \mathrm{R} / \mathrm{C}=\frac{\text { Penerimaan }(T R)}{\text { Biaya } \operatorname{Total}(T C)}$

Kriteria:

R/C > 1, Hasil usahatani menguntungkan

$\mathrm{R} / \mathrm{C}<1$, Hasil usahatani tidak menguntungkan.

$\mathrm{R} / \mathrm{C}=1$, Hasil usahatani dikatakan impas. 


\section{HASIL DAN PEMBAHASAN}

\section{Identitas Petaui Responden}

Identitas petani responden merupakan latar belakang kehidupan petani yang sangat besar pengaruhnya dalam kegiatan usahatani kakao. Identitas responden yang dimaksud adalah: umur, tingkat pendidikan, jumlah tanggungan keluarga dan pengalaman berusahatani kakao.

\section{a. Umur Responden}

Umur responden dalam penelitian ini bila ditinjau dari umur responden produktif dan kurang produktif, maka yang mempunyai umur produktif ( 26-54) adalah 24 orang atau $80 \%$ dan umur non produktif adalah 6 orang atau $10 \%$. Untuk lebih jelasnya dapat dilihat pada Tabel 1

Tabel 1. Pengelompokan Menurut Umur (Produktif dan Kurang Produktif).

\begin{tabular}{cccc}
\hline No & Kel.Umur (Tahun) & Jumlah (Orang) & Prsentase (\%) \\
\hline 1. & $28-54$ & 28 & 90,00 \\
\hline 2. & 55 keatas & 3 & 10,00 \\
\hline & Jumlah & 30 & 100,00
\end{tabular}

Tabel 1 terlihat bahwa sebagian besar petani responden berada pada kelompok umur produktif sebanyak $90 \%$ dan selebihnya berada pada umur kurang produktif. Petani yang berumur produktif akan berdampak positif da lam menjalankan usahataninya. Dalam usia yang relatif muda ini memungkinkan petani responden memiliki kemampuan fisik dan pola berpikir yang lebih baik, lebih dinamis dan lebih berani menanggung resiko dalam menerima dan menerapkan teknologi.

\section{b. Tingkat Pendidikan}

Pendidikan merupakan salah satu faktor yang mempengaruhi petani responden dalam berpikir dan bertindak. Umumnya makin tinggi tingkat pendidikan seseorang akan semakin mudah menerima sesuatu yang sifatnya baru dan lebih terampil serta dinamis dalam menerima setiap perubahan dan menerapkan apa yang didapatnya kearah yang lebih baik. Pendidikan petani responden dalam penelitian ini adalah tingkat pendidikan formal yang pemah dilalui petani responden. Untuk lebih jelasnya dapat dilihat pada Tabel 2.

Tabel 2. Tingkat Pendidikan Petani.

\begin{tabular}{clcc}
\hline No. & Tingkat Pendidikan & Jumlah (Orang) & Persentase (\%) \\
\hline 1. & Tamat SD & 12 & 40,00 \\
\hline 2. & Tamat SMP & 17 & 56,67 \\
\hline 3. & Tamat SMU & 8 & 26,63 \\
\hline & Jumlah & 30 & 100,00
\end{tabular}


Tabel 2 menunjukkan bahwa umumnya responden yang berpendidikan Sekolah Dasar adalah 12 orang atau 40\%. Petani yang berpendidikan SMP sebanyak 17 orang atau 56,67\% Sedangkan pendidikan tertinggi yang dicapaipetani responden adalah SMU sebanyak 8 orang (26,63\%). Dengan tingkat pendidikan yang dimiliki petani responden, diharapkan mereka mampu menerima setiap informasi yang disampaikan kepadanya, khususnya dalam hubungannya dengan pengembangan usahatani kakao. Kenyataan ini menggambarkan bahwa tingkat pendidkan petani responden masih tergolong rendah, sehingga perlu bantuan penyuluh dalam memberikan pendidikan tambahan pengetahuan agar petani tidak kesulitan dalam menerima dan menerapkan inovasi - inovasi baru.

\section{c. Pengalaman Berusahatani}

Pengalaman berusatani dapat dikatakan cukup berpengalaman apabila menggeluti bidang pekerjaannya selama 5 -10 Tahun. Sedangkan 10 Tahun keatas dikategorikan berpengalaman dan kurang dari 5 tahun dikategorikan kurang berpengalaman. (Soeharjo dan Dahlan Patong, 1984). Gambaran mengenai petani berdasarkan pengalaman berusahatani dapat dilihat pada Tabel 3.

Tabel 3. Pengalaman Berusahatani Petani Tahun 2013.

\begin{tabular}{cccc}
\hline No & $\begin{array}{c}\text { Pengalaman Berusahatani } \\
\text { (Tahun) }\end{array}$ & $\begin{array}{c}\text { Jumlah } \\
\text { (Orang) }\end{array}$ & $\begin{array}{c}\text { Presentase } \\
(\%)\end{array}$ \\
\hline 1. & $5-10$ & 7 & 23,00 \\
\hline 2. & $11-20$ & 23 & 77,00 \\
\hline & Jumlah & 30 & 100,00 \\
\hline
\end{tabular}

Tabel 3 menunjukkan bahwa sebagian besar petani responden memiliki pengalaman antara 11 - 20 tahun sebanyak 23 orang atau $77 \%$ sedangkan petani yang memiliki pengalaman $5-10$ Tahun sebanyak 7 orang atau 23\%. Kenyataan ini menggambarkan bahwa sebagian besar petani dikatakan berpengalaman dalam mengelola usahatani kakao sebanyak 23 orang atau 77\%. Sebagaimana mengacu pada pendapat Soehardjo dan Patong (1984) bahwa seseorang dikatakan berpengalaman apabila telah menggeluti kegiatan usahatani diatas 10 tahun. Dengan keadaan yang berpengalaman tersebut diharapakan petani dapat mengelolah kegiatan usahatani kakao dengan baik dalam artian setiap keputusan yang diambil selalu penuh pertimbangan berdasarkan pada pengalaman yang telah dilaluinya dan biasanya semakin lama (banyak) pengalamannya maka semakin baik dalam mengelola usahataninya karena pengalaman merupakan guru besar atau pelajaran berharga dalam melakukan suatu perubahan yang pada akhimya dapat meningkatkan produksi dan pendapatannya.

\section{d. Jumlah Tanggungan Keluarga}

Tanggungan keluarga merupakan salah satu sumber daya manusia yang dapat dikembangkan untuk membantu kepala keiuarga, utamanya anggota keluarga yang berusia produktif. Tanggungan keluarga yang berusia produktif akan memberikan curahan kerja dalam proses produksi usahatani. Kepala keluarga dalam kedudukannya sebagai anggota masyarakat, termasuk sebagai petani, berusaha untuk memenuhi kebutuhan keluarganya dan tuntutan dari luar keluarganya. Makin besar tanggungan keluarga, makin besar pula usaha yang dilakukan untuk memenuhi kebutuhan keluarganya. 
Adapun jumlah tanggungan keluarga responden dalam penelitian ini berkisar antara 2 sampai 7 orang. Untuk lebih jelas tentang jumlah tanggungan keluarga responden dapat dilhat pada Tabel 4.

Tabel 4. Jumlah Tanggungan Keluarga Petani Tahun 2013

\begin{tabular}{cccc}
\hline No & Jumlah Tang. Kelg (Jiwa) & Jumlah (Orang) & Persentase (\%) \\
\hline 1 & $2-4$ & 23 & 77,00 \\
\hline 2 & $5-7$ & 7 & 23,00 \\
\hline & Jumlah & 30 & 100,00
\end{tabular}

Tabel 4 menunjukkan bahwa sebagian besar petani responden mempunyai tanggungan keluarga antara 2-4 jiwa sebanyak 23 orang (77\%). Sisanya 7 orang atau $23 \%$ dengan jumlah tanggungan keluarga antara5-7 jiwa. Diharapkan dengan jumlah tanggungan keluarga yang ada dapat membantu petani dalam mengelolah kegiatan usahatani kakao.

Tanggungan keluarga yang berada pada usia produktif dapat membantu petani dalam melakukan kegiatan usahatani kakao yang dikelolanya. Disamping itu dapat pula berfungsi sebagai teman petani dalam mempertimbangkan keputusan yang akan diambil, bahkan dapat berfungsi sebagai sumber informasi terhadap hal-hal yang belum diketahui oleh petani. Tanggungan keluarga yang tergolong kurang produktif biasanya hanya menjadi beban petani dan keterlibatannya dalam kegiatan usahatani juga kecil.

Jumlah tanggungan keluarga yang besar menyebabkan besarnya biaya hidup rumah tangga petani, sehingga hal ini akan mendorong petani untuk lebih giat dan tekun dalam berusaha guna memperoleh hasil yang maksimal untuk memenuhi kebutuhan hidup keluarganya.

\section{Deskripsi Usahatani}

Deskripsi usahatatani merupakan gambaran keadaan usahatani petani responde dalam melakukan kegiatan usahataninya. Deskripsi usahatani yang dimaksud antara lain : luas lahan yang digarap, biaya-biaya yang dikeluarkan baik biaya tetap maupun biaya variabel, jumlah produksi kakao yangdihasilkan, harga jual kakao ditingkat petani, dan pendapatan yang diterima.

\section{a. Luas Lahan Garapan}

Berdasarkan hasil penelitian yang dilakukan di Desa Siontapina menunjukan bahwa petani responden memiliki lahan garapan rata-rata 2,05 Hektar yang berkisar antara 1-4 Hektar. Petani responden yang memiliki luas lahan diatas rata-rata lebih kecil sebanyak 8 orang atau $27 \%$ dari jumlah petani responden yang memiliki luas lahan dibawah rata- rata sebesar $73 \%$. Untuk lebih jelasnya dapat dilihat pada Tabel 5.

Tabel 5. Deskripsi Usahatani Kakao Menurut Luas Lahan Garapan Petani Tahun 2013.

\begin{tabular}{cccc}
\hline No & Luas Lahan Garapan (Ha) & Jumlah (orang) & Persentase(\%) \\
\hline 1 & 1 & 8 & 26,67 \\
\hline
\end{tabular}


Vol. 2, Issue 2, November 2018

P-ISSN: 2527-8479

\begin{tabular}{lccc}
\hline & & & \\
\hline 2 & 2 & 18 & 60,00 \\
\hline 3 & 3 & 14 & 46,63 \\
\hline & Jumlah & 30 & 100,00 \\
\hline
\end{tabular}

Tabel 5 menunjukan bahwa luas lahan garapan yang dikelola petani responden sebagian besar berada dibawah rata-rata luas lahan. Kenyatan ini menunjukan bahwa petani responden dengan luas lahan yang dikelola walaupun lebih banyak berada pada kondisi dibawah rata-rata luas lahan (1-3 Hektar) yang ada di Desa Siontapina tapi dapat memaksimalkan penggunaan faktor-faktor produksi yang lain sehingga dapat mencapai produksi yang maksimal dan pada akhirnya kesejahteraannya tercapai dengan pendapatan yang mereka peroleh.

\section{b. Produksi}

Salah satu keberhasilan usahatani yang dikelolah petani kakao adalah jumlah produksi yang dihasilkan. Produksi yang dimaksud adalah jumlah produksi kakao yang dihasilkan dalam satu tahun yang diukur dalam satuan $\mathrm{Kg}$. Produksi yang tinggi dapat diperoleh dengan pemanfaatan faktor-foktor produksi yang ada secara seimbang. Sebagaimana Mubyarto (1986), bahwa produksi adalah banyaknya hasil fisik yang dapat diperoleh dari satu kesatuan faktor produksi (input). Jadi, produksi usahatani merupakan hasil kerjasama dari faktor-faktor produksi yang dimiliki.

Hasil penelitian yang dilakukan menunjukan bahwa rata-rata produksi yang dihasilkan oleh petani responden adalah $1.286 \mathrm{Kg}$ dengan produksi berkisar antara 500-2800 Kg. Tingkat produksi kakao yang dihasilkan petani responden di Desa Siontapina dapat dilihat pada Tabel 6.

Tabel 6. Produksi Usahatani Kakao Petani Tahun 2013.

\begin{tabular}{cccc}
\hline No & Produksi $(\mathrm{Kg})$ & Jumlah $($ Orang) & Persentase $(\%)$ \\
\hline 1 & $600-1.200$ & 20 & 66,67 \\
\hline 2 & $1.201-2.200$ & 10 & 33,33 \\
\hline & Jumlah & 30 & 100,00 \\
\hline
\end{tabular}


Tabel 6 menunjukkan bahwa sebagianbesar petani responden yaitu sebayak 20 orang atau 66,67\% mampu menghasilkan produksi kakaoberada diatas rata-rata produksi dan 10 petani responden atau 33,33\% mampu menghasilkan produksi dibawah rata-rata. Jika produksi dihitung dalam perhektarnya maka kisaran produksi dari $1.2010 \mathrm{Kg}-2.200 \mathrm{Kg}$. Kenyataan ini menunjukan bahwa sebagian besar petani responden dengan luas lahan yang dimiliki telah mampu mengelola usahataninya dengan baik dalam artian telah menerapkan teknologi sesuai anjuran yang meliputi penggunaan pupuk, obat-obatan dan melakukan pemeliharaan dalam melakukan kegiatan usahatani kakao. Hasil produksi yang dihasilkan selanjutnya dijual untuk mendapatkan sejumlah uang tunai yang digunakan untuk keperluan sehari-hari dan untuk disimpan sebagai modal.

\section{c. Biaya}

Dalam melakukan kegiatan usahatani kakao, petani tentunya tidak terlepas dari biayabiaya yang harus dikeluarkan untuk menunjang keberhasilan usahataninya. Biaya - biaya yang diperhitungkan dalam penelitian ini adalahi biaya tetap dan biaya variabel yang meliputi pembelian pupuk, obat-obatan, upah tenaga kerja, biaya penyusutan alat dan pajak lahan. Biaya-biaya yang dikeluarkan petani responden dapat dilihat pada Tabel 7

Tabel 7. Rata - Rata Biaya Petani Tahun 2013.

\begin{tabular}{clc}
\hline No. & \multicolumn{1}{c}{ Jenis Biaya } & Biaya Rata - rata (Rp) \\
\hline 1. & Penyusutan alat & 100,033 \\
\hline 2. & Pajak lahan & 150.383 \\
\hline 3. & Pupuk & 1.876 .767 \\
\hline 4. & Obat-obatan & 1.292 .033 \\
\hline 5. & Pemupukan & 108.033 \\
\hline 6. & Penyemprotan & 140.500 \\
\hline 7. & Panen & 107.500 \\
\hline 8. & Pengangkutan & 154.00 \\
\hline & & 3.930 .050
\end{tabular}

Tabel 7 menunjukan rata- rata biaya yang dikeluarkan petani responden untuk penggunaan lahan rata- rata 2,05 Hektar adalah sebesar Rp.3.930.050.

\section{d. Penerimaan}

Produksi yang diperoleh dari usahatani kakao merupakan hasil kombinasi dari penggunaan faktor - faktor produksi yang nantinya hasilnya akan digunakan untuk memenuhi kebutuhan petani dan seluruh keluarganya serta untuk modal usaha sebagai langkah pengembangan usahatani kakao yang lebih maju.

Dari besamya produksi yang diperoleh maka dapat diketahui besamya nilai penerimaan dari usahatani kakao. Harga kakao yang berlaku pada saat penjualan adalah Rp.19.000/Kg. 


\section{e. Pendapatan}

Dalam kegiatan usahatani memiliki skala pendapatan untuk melihat tingkat kesejahteraan hidup petani dalam kehidupan sehari-hari. Pendapatan yang tinggi bukan hanya diperleh dari besarnya produksi tetapi sangat dipengaruhi oleh harga serta tinggi rendahnya biaya faktor produksi yang digunakan. Posisi pengeluaran dan pendapatan kotor, yang dikeluarkan danyang diterimanya akan menggambarkan keadaan usahataninya, apakah mengalami keuntungan atau kerugian.

Pendapatan yang dimaksud dalam penelitian ini adalah selisih antara jumlah penerimaan dengan seluruh biaya yang dikeluarkan oleh petani responden. Berdasarkan hasil penelitian diperoleh bahwa pendapatan rata-rata petani responden sebesar Rp.18.426.767/Tahun. Dengan kisaran pendapatan antara Rp.8.109.000 - Rp.35.437.000. Berdasarkan hasil penelitian yang dilakukan menunjukan bahwa jumlah petani responden terbesar adalah 16 orang atau $63 \%$ dengan pendapatan yang diperoleh diatas rata-rata pendapatan di desa tetehaka, sedangkan jumlah petani responden terkecil 14 orang atau 47\% dengan pendapatan yang diperoleh dibawah rata-rata. Untuk lebih jelasnya dapat dilihat pada Tabel 8.

Tabel 8. Deskripsi Usahatani Kakao Menurut Tingkat Pendapatan Petani Tahun 2013.

\begin{tabular}{cccc}
\hline No & $\begin{array}{c}\text { Tingkat Pendapatan } \\
\text { (Rp/tahun) }\end{array}$ & $\begin{array}{c}\text { Jumlah } \\
\text { (orang) }\end{array}$ & $\begin{array}{c}\text { Persentase } \\
(\%)\end{array}$ \\
\hline 1. & $8.109 .000-17.218 .334$ & 14 & 47,00 \\
\hline 2. & $17.218 .335-26.327 .668$ & 10 & 13,00 \\
\hline 3. & $26.377 .669-35.437 .669$ & 6 & 20,00 \\
\hline & Jumlah & 30 & 100,00
\end{tabular}

*Rata-rata pendapatan

Berdasarkan tabel 8 menunjukan bahwa dari hasil pendapatan yang diterima oleh keseluruhan petani responden dari usahatani kakao sudah dapat dikatakan bahwa untuk pemenuhuhan kebutuhan minimum sehari-hari sudah lebih dari cukup Sebagaimana berdasarkan Badan Pusat Statistik Indonesia (2004) mencatat kemiskinan penduduk Propinsi Sulawesi Tenggara sebesar Rp.128,687 perkapita perbulan. Dalam hal ini bahwa petani responden yang mengusahakan usahatani kakao di Desa Siontapina dapat dikategorikan tidak miskin karena dari hasil pendapatan yang terendah diperoleh petani responden sebesar Rp.675.750 perkapita perbulan.

Berdasarkan data yang diperoleh dan dianalisis untuk mengetahui kelayakan usaha menunjukan bahwa usahatahani kakao yang dilakukan di Desa Siontapina tersebut layak diusahakan dan dikembangkan lebih lanjut. Hal ini dapat dilihat dari hasil analisis yaitu :

Kelayakan usaha

$=\frac{\text { Total penerimaan }}{\text { Total biaya }}$ 
$=\frac{671.270 .000}{117.901 .500}$

$=5,7$

Berdasarkan hasil yang diperoleh menunjukan bahwa dari luas lahan rata-rata 2.05 Hektar yang digarap oleh petani di daerah penelitian dengan biaya yang dikeluarkan menghasilkan nilai 5,7 Nilai yang diperoleh tersebut memberikan gambaran bahwa setiap Rp.1 biaya yang dikeluarkan petani dalam mengelolah kegiatan usahatani kakao tersebut memperoleh penerimaan sebesar Rp.5,7.

\section{KESIMPULAN DAN SARAN}

\section{Kesimpulan}

Berdasarkan hasil analisis dan pembahasan, maka dapatdikemukakan beberapa kesimpulan sebagai berikut:

1. Pendapatan yang diterima oleh petani responden dari usahatani kakao dengan luas lahan berkisar antara 1 - 3 hektar sebesar Rp.8.109.000 - Rp.35.437.000/Tahun, dengan pendapatan perkapita perbulan rata Rp.675.750. Sehingga Desa Siontapina dikategorikan tidak miskin.

2. Pendapatan rata-rata yang diterima oleh petani responden pada usahatani kakao dengan luas lahan rata- rata 2,05 Hektar Rp.18.426.767/Tahun.

3. Usahatani kakao yang dilakukan oleh petani responden tetap dilakukan sebab berdasarkan hasil analisis kelayakan usaha diperoleh nilai sebesar 5,7. Hal ini memberikan gambaran bahwa setiap Rp.1 biaya yang dikeluarkan oleh petani responden akan memperoleh penerimaan sebesar Rp.5,7.

2. Saran berikut:

Berdasarkan kesimpulan di atas, dapat dikemukakan beberapa saran sebagai

1. Diharapkan kepada para petani agar tetap melakukan kegiatan usahatani kakao dan lebih responsif dan tanggap terhadap adanya teknologi atau input-input baru yang dapat meningkatkan produksi kakao.

2. Diharapkan kepada petani dalam melakukan kegiatan usahatani kakao perlu mengintensifkan kegiatan pemeliharaan sehingga dapat menghasilkan produksi yang maksimal

3. Kepada para penyuluh agar tetap melakukan kegiatan penyuluhan dan pelatihan yang lebih intensif sehingga petani dapat meningkatkan pengetahuan dan ketrampilan yang dimiliki petani.

\section{DAFTAR PUSTAKA}

Adikoesoemah, 1982. Biaya dan Harga Pokok. Tarsito, Bandung.

Adiwilaga, Anwas, 1982. Ilmu Usahatani. Alumni, Bandung.

Anonim, 2010. Badan Pusat Statistik Bombana. Bombana.

Arsyad, 1999. Prinsip Dasar Ekonomi Pertanian : Teori dan Aplikasinva, Edisi Revisi. Rajawali Press, Jakarta.

Anwari, 1980. Pengantar Ekonomi Perusahaan. Alumni, Bandung.

Badan Pusat Statistik Indonesia, 2009. Statistik Indonesia. Jakarta. 


\section{Media Agribisnis}

Vol. 2, Issue 2, November 2018

P-ISSN: 2527-8479

Banoewidjoyo, Moeljadi, 1983. Pembangunan Pertanian. Usaha Nasional, Surabaya

Billas, 1985. Teori Ekonomi Mikro. Erlangga, Jakarta.

Budiono,1992. Ekonomi Mikro. Badan Penerbit Fakultas Ekonomi.

Gilarso, 1994. Pengantar Ekonomi Bagian Mikro. Kanisius, Yogyakarta.

Hemanto, Fadholi, 1995. Ilmu Usahatani. Penebar Swadaya, Jakarta.

Karsino, dkk, 1980. Pola tanam: Aplikasi teknologi Pertanian, intensifikasi tanaman Pangan dan Pola Usahatani. Sensus Pertanian 1983. Biro Pusat Statistik, Jakarta.

Komaruddin, 1985. Ensklopedi Manajemen. Alumni. Bandung

Lipsey. 1993. Pengantar Ekonomi Mikro. Erlangga, Jakarta. 